JOURNAL OF ENGINEERING SCIENCES

ЖУРНАЛ ІНЖЕНЕРНИХ НАУК

ЖУРНАЛ ИНЖЕНЕРНЫХ НАУК

Web site: http://jes.sumdu.edu.ua

DOI: $10.21272 /$ jes.2019.6(1).c3

Volume 6, Issue 1 (2019)

UDC 620.178:621.793

\title{
Increased Wear Coatings due Intrastructural Self-Correction
}

Babak V. P., Bilchuk Ye. Yu. ${ }^{*}$, Shchepetov V. V.

Institute of Engineering Thermophysics of National Academy of Sciences of Ukraine, 2a Zhelyabova St., 03057 Kyiv, Ukraine

\author{
Article info: \\ Paper received: \\ The final version of the paper received: \\ Paper accepted online:
}

August 29, 2018

December 13, 2018

December 17, 2018
*Corresponding Author's Address: admin@ittf.kiev.ua

\begin{abstract}
A mechanism for blocking and subsequent annihilation of endogenous microcracks due to their intrastructural self-correction has been proposed. It has been established that during tribomechanical processes of friction interaction under conditions of additive influence of temperature fluctuations and specific loads in the contact zone, all possible factors take place simultaneously, from the point of view of physicochemical anomalous transformations in the solid phase, as a result of which thermal destruction of carbides and the formation of structurally free $\alpha$ graphite. The test results prove that the anti-friction surface layer, which contains graphite, is formed in the run-in regime. The composition and the equilibrium roughness of the surface layer are reproduced and maintained throughout the normal range of wear, and also form an integral system of dynamically stable wear-resistant structures.
\end{abstract}

Keywords: detonation spraying, wear resistance, surface layer, structural adaptability, doping.

\section{Introduction}

Among the technological problems that are associated with the surface strength of metallic materials under friction, damageability, as opposed to the regeneration process, is of particular importance. There are many types of damage, and the results are often the idem. The process can be represented as the result of nucleation and subsequent growth of cracks, the onset of which is preceded by plastic deformation. The study of the processes of nucleation and development of destruction, as well as the inhibition and regeneration of cracks in materials, is an actual task.

Papers [1, 2] present the results of studying the laws of the effect of all-round pressure and temperature on the kinetics of the process of healing the pores and cracks of grain boundaries in polycrystalline materials. In [3, 4], data on the transformation of defects such as flat microcracks in the material of parts under the influence of a high-energy pulsed electromagnetic field were obtained. The processes that occur in the material during the processing of metal samples with short pulses of highdensity electric current are also researched. In [5, 6], the results of processing a pulsed magnetic field of samples with a crack on their resistance to fracture are presented. It is noted that the action of a pulsed magnetic field causes stress relaxation due to plastic flow at the crack tip. Note that the tip of the crack is often blunted. In [7, 8], studies of the structure and properties of metals, the deformation of which occurs at high constantly operating hydrostatic pressures, are analyzed. In this case, as established, the greater the compressive stresses, the more plastic deformation the material can undergo without destruction.

Describing the overall state of research, both in our country and in the world, it can be noted that the existing technologies are ineffective, their implementation presents certain difficulties in operating conditions, especially in non-stationary conditions, and does not have a simple and reliable solution for real production.

In the surface layers, under friction loading, microcracks and pores are formed, the kinetic development of which determines the durability resource of moving couple. However, in turn, the creation of conditions for their inhibition and regeneration may be one of the promising ways to improve the wear resistance and durability of parts.

The aim of the work is to study ways to improve wear resistance due to intrastructural self-correction of endogenous microcracks with carbon nanotubes. 


\section{Research Methodology}

Detonation spraying of nanoscale composite coatings was formed with $\mathrm{Nb}-\mathrm{V}-\mathrm{Si}$ nanopowders [9]. Nanopowders were obtained by the method of mechanochemical synthesis with the subsequent addition, according to the developed technology, of carbon frame structures in the form of nanotubes. The maximum length of the nanotubes was about a hundred micrometers. The deformation energy of nanotubes is inversely proportional to the square of the radius; therefore, nanotubes with a diameter of tens of micrometers were used.

The wear resistance of the researched coatings was evaluated by the friction of model samples according to the end contact scheme with a distributed load and in the absence of lubricant. The tests were carried out in continuous slide mode with a load of 10.0 MPa. The thickness of the coatings after final processing was $0.20-0.30 \mathrm{~mm}$ with roughness $\mathrm{Ra}=0.63-0.32$. At the same time, coatings of the same composition, but not containing carbon nanotubes, as well as the traditionally used coatings of tungsten-containing powders of the type VC15 and doped on the basis of nickel, were tested using the same method.

A metallographic research of samples of coatings was done taking into account the specifics of the tasks being solved, by appropriate methods of complex physicochemical analysis.

\section{Results}

The main factors that determine the development of mechanochemical processes of friction and which determine the degree and gradients of elastoplastic deformation, temperature effects, structural phase transformations, and, ultimately, the main type of wear, are the speed of relative movement, load, temperature, environment. At the same time, there is a stable correlation of tribology parameters with plastic deformation processes [10].

The test results of the researched coatings (Fig. 1) by the dependences of the wear intensity on the sliding speed at a constant load of $10 \mathrm{MPa}$.

As can be seen, nanoscale coatings of the Nb-V-Si system with carbon framework structures (nanotubes) have the smallest breaking-in duration, wear rate and friction coefficient (Fig. 1, curves 1 and 1'). Moreover, it should be noted that changes in friction coefficients are consistent with the profile of the wear intensity curve, and its stability over time with a monotonous increase in the sliding speed indicates a high performance of the coating material, for which the main is mechanochemical wear.

The results of micro X-ray spectroscopic and X-ray phase physicochemical studies of nanoscale $\mathrm{Nb}-\mathrm{V}-\mathrm{Si}$ coatings with carbon nanotubes made it possible to classify them as a thin-differentiated phase mixture with an average grain size of 35-60 $\mathrm{nm}$ and an almost homogeneous distribution over the section.

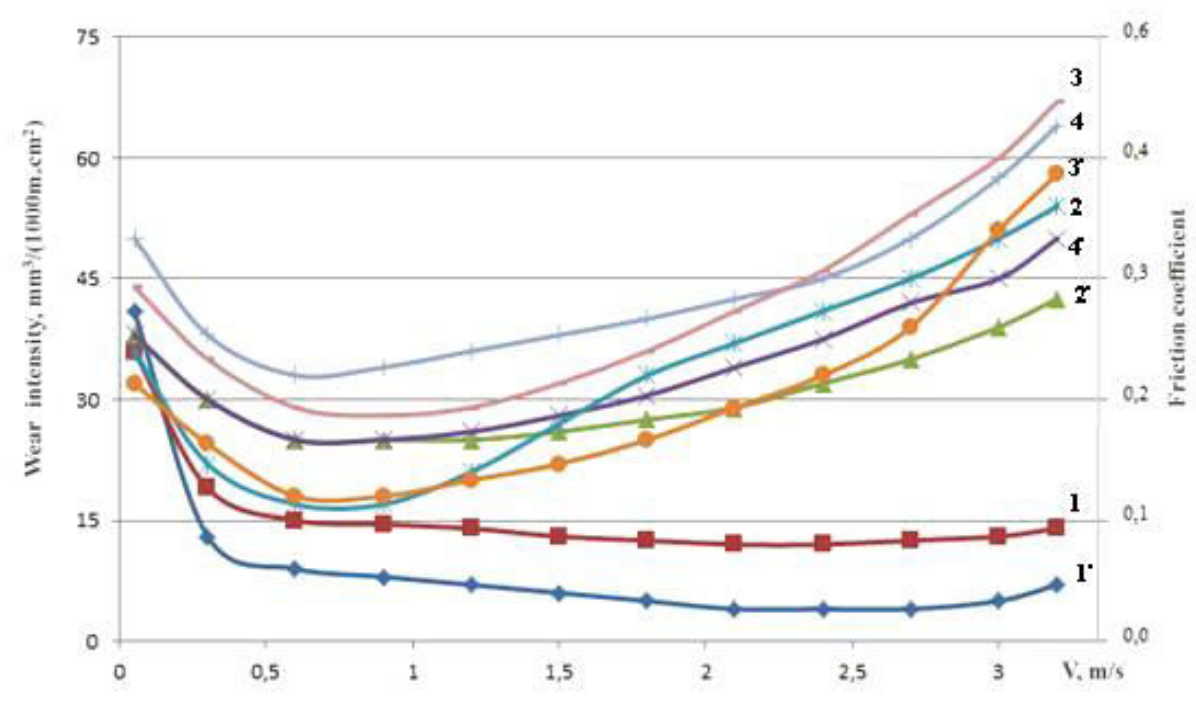

Figure 1 - The dependence of wear intensity (1-4) and friction coefficients ( $\left.1^{\prime}-4^{\prime}\right)$ on the sliding speed of coatings:

1, 1' - Nb-V-Si nanoscale system containing carbon nanotubes; 2, 2' - type VK15 (WC-Co);

3, 3' - nanoscale composition of $\mathrm{Nb}-\mathrm{V}-\mathrm{Si} ; 4,4$ '- based on nickel (Ni-Cr-Al-B)

However, fragments of imprints obtained in absorbed electrons and X-rays, which correspond to individual bunches with local heterogeneity, were also recorded. Their ultrafine structure differs from granular and is close to thin-lamellar formations. In our opinion, they are due both to nanoscale and to the fact that, during X-ray studies, the main contribution to the interference function is made by metal atoms, since the atomic scattering factor for them is much larger than for metalloids. In addition, their content is more.

To determine the properties of nanoscale composite coatings and their interaction under operating conditions, regularities of interaction of the components included in their composition were established.

It is established that a conglomerate of ultradispersed coating components are, first of all, chemical compounds 
and mechanical mixtures of different composition, size and shape.

The presence of the matrix phase in the form of solid solutions of $\mathrm{Nb}$ with $\mathrm{V}$ and $\mathrm{Si}$, as well as ternary solid solutions with inclusions of chemical compounds of the VSi type has been established. It should be noted that the presence of $\mathrm{V}$ and $\mathrm{Si}$ contributes to an increase in the recrystallization temperature of $\mathrm{Nb}$. Different sizes, but with the same distribution over the cross section, were determined, strengthening the phases of niobium and vanadium silicide's $\left(\mathrm{Nb}_{5} \mathrm{Si}_{3}, \mathrm{NbSi}_{2}, \mathrm{~V}_{5} \mathrm{Si}_{3}, \mathrm{VSi}_{2}\right.$, etc. $)$ and niobium and vanadium intermetalic metal. The presence of niobium, vanadium, silicon carbides $\left(\mathrm{NbC}, \mathrm{VC}, \mathrm{V}_{2} \mathrm{C}\right.$, $\mathrm{SiC}$ ) and carbide compounds of the type $\mathrm{Me}_{\mathrm{m}}^{\prime} \mathrm{Me}_{\mathrm{m}} \mathrm{C}$ $\left(\mathrm{Si}_{2} \mathrm{~V}_{2} \mathrm{C}, \mathrm{Si}_{2} \mathrm{Nb}_{2} \mathrm{C}\right)$ distributed throughout the coating volume was also established.

In thin-dispersed surface compositions, the main role of substructural components becomes. They have both an extraordinary chemical activity, which is due to a nanoscale level, and a significant ability to exchange energy and matter with the environment, and are in very nonequilibrium conditions. Therefore, the formation of surface structures can be considered as self-organization processes, as a result of which dynamically stable solidphase wear-resistant structures are formed.

The principal feature of the introduction of carbon frame formations (nanotubes) into the composition of nanoscale coatings is due to the evolution of their carbon atoms under activation conditions. In the process of forming a homogeneous powder mixture under conditions of mechanochemical synthesis, the carbon atoms of the end layers of the nanotubes are activated and, as a result of selective thermal diffusion interaction, form stable chemical compounds. In addition, as a result of detonation gas spraying under conditions of structural thermal activation, carbon atoms initiate bonds with the metal atoms of the surface layer, providing the formation of secondary structures.

The process of structural activation is determined by the kinetics of nucleation and movement of the imperfections of the crystal structure in the deformation zone, which, in turn, is related to the energy state of the atoms, which depends on thermal activation due to their small size, activated carbon atoms, leaving the framework structure of nanotubes, easily diffuse and their cooperative clusters migrate to the places of formation of microcracks with excess surface energy. The atomic bonds formed due to the chemical and van der Waals attraction forces contribute to the creation of interatomic bonds and as a result of blocking the development of cracks and their subsequent annihilation. Thus, carbon nanotubes are actively involved in surface carbonization and providing the formation of an anti-friction film chemically bonded to the surface of the nanoscale layer. They are also a source of active carbon capable of long-term migration and chemical interaction during the healing of defects in the crystal structure. That is, to reduce their concentration, especially in the near-surface layers, where both dislocation clusters and microcracks are concentrated.
Figure 2a illustrates typical micrographs of friction surfaces. A micrograph of the working surface of the sample of the Nb-V-Si coating, which does not have carbon nanostructures and for which the development of the initial phase of irreversible processes of deformation and damage is typical.

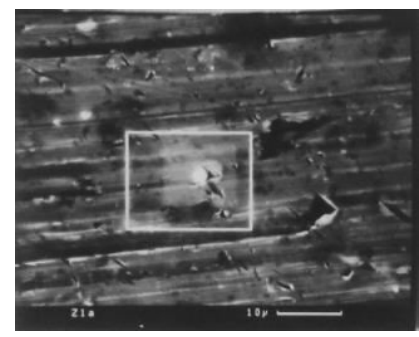

$\mathrm{a}$

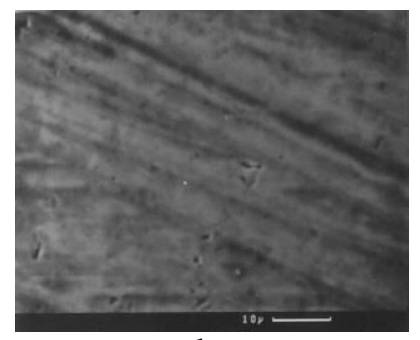

b
Figure 2 - Friction surfaces: $\mathrm{a}$ - coatings $\mathrm{Nb}-\mathrm{V}-\mathrm{Si} ; \mathrm{b}-\mathrm{Nb}-\mathrm{V}-\mathrm{Si}$ coating with carbon nanotubes $(2.7 \mathrm{~m} / \mathrm{s}, 10.0 \mathrm{MPa})$

The surface of the Nb-V-Si coating with carbon nanotubes (Figure 2b), there are no signs of macroscopic damage. The friction surface is covered with a continuous film of mostly dark color, has no defects, cracks, signs of chipping, which confirms its high plasticity and adhesive strength.

X-ray spectral microanalysis of the friction surface determined the presence of a film of $\alpha$-graphite on the nanocoating with carbon nanotubes. This, according to the authors, is explained by the structural-energy factor. In more detail, the energy partially accumulated by the friction surface is concentrated, as is known, in the thinnest layer (about hundreds of nanometers) and its density in the element of the activated coating volume is close to the critical amount of energy that a material can absorb before destruction.

The high density of stored energy under the conditions of tribomechanical contact interaction processes, with the additive influence of temperature fluctuations and specific pressures, causes the simultaneous initiation of virtually all possible physicochemical anomalous transformations in the solid phase in the friction zone. Also, as a result of the thermal decomposition of carbides, structurally free $\alpha$-graphite is released, on the basis of which an anti-friction surface film is formed.

\section{Discussion}

The test results show that a protective surface thin-film layer with graphite is formed already during the runningin process. The composition of the surface layer and the equilibrium roughness are reproduced throughout the entire range of normal operation and remain practically constant, which provides the stability of the indications of friction coefficients. At the same time, the metal atoms after the partial destruction of surface carbides form silicide and, for the most part, oxide phases. Oxide phases, as shown by submicrostructural studies, fill the surface microscopic microroughnesses, microcracks and are fixed 
in the micropins of the contacting surfaces. Their antiwear and antifriction effects, according to the authors, persist for a long time and correspond to the entire period of normal operation of the coupling surfaces and are not associated only with the running-in period.

Obtaining an energy level corresponding to a change in the specific work of destruction, as shown by calculations, from $10 \mathrm{~kJ} / \mathrm{mm}^{3}$ to $85000 \mathrm{~kJ} / \mathrm{mm}^{3}$, causes the completion of the burn-in process and determines the parameters of friction. The friction parameters, in turn, are characterized by minimizing the wear rate, correlation with friction coefficients, stable roughness and the formation of optimal structures, as well as the properties of the surface layers that cause the flow of normal wear.

Figure 3 illustrates the friction surfaces of the coating with carbon nanotubes corresponding to the mechanochemical wear mode with the display of the kinetics of the local microcrack self-correction process.

Under the conditions of steady mechanochemical wear, using electron microscopic studies using the dark field method, it was possible to establish that the inner surface zone is a carbide-oxide conglomerate of nanoscale particles chemically bound to the base material. The outer surface object consists of a thin graphite layer with nanoscale inclusions that cannot be fully identified. However, in our opinion, they even in nanovolumes have a complex phase composition and consist of a mixture of $\mathrm{Nb}_{2} \mathrm{O}_{5}(\mathrm{NbO}), \mathrm{V}_{2} \mathrm{O}_{5}, \mathrm{SiO}_{2}$.

In accordance with modern views, destruction is not an instantaneous act, but is a process that develops over time. From the standpoint of kinetics, the moment of formation of a crack of critical size, capable of spreading spontaneously without receiving external energy (according to the Griffith mechanism), is preceded by the gradual accumulation of foci of destruction in the form of endogenous microcracks.

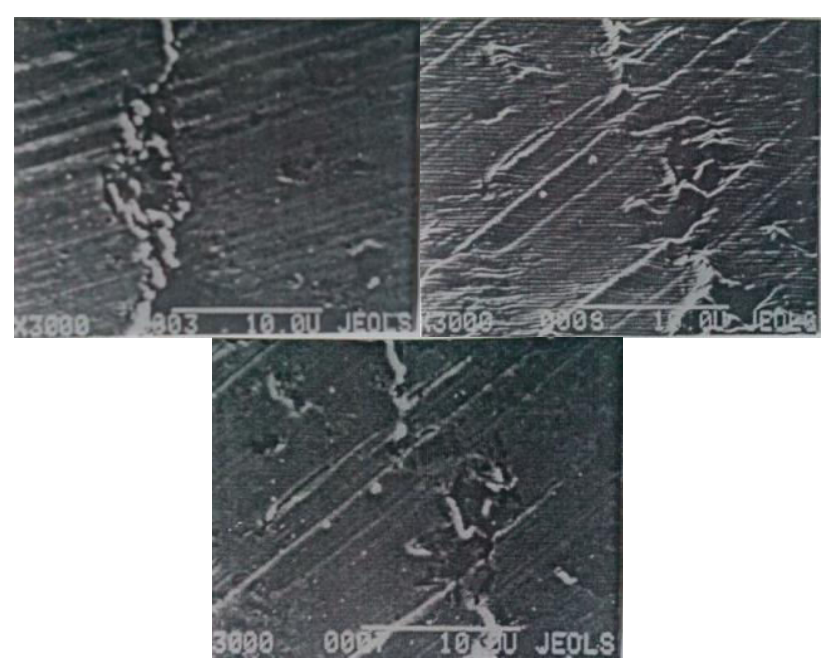

Figure 3 - Friction surfaces of $\mathrm{Nb}-\mathrm{V}-\mathrm{Cu}$ coating with carbon nanotubes, illustrating the kinetics of the process of selfcorrection of a transverse microcrack $(2.5 \mathrm{~m} / \mathrm{s}, 10.0 \mathrm{MPa})$
The initiation of the phenomenon of intrastructural self-correction of endogenous microcracks in the nearsurface layers of coatings is initiated, firstly, with activated carbon atoms, and secondly, with the self-consistency of two complementary processes. On the one hand, the working temperature reaches about $0.2-0.3 \mathrm{Tm}$, on the other hand, the action of compressive stress fields covering the volume of microcracks, at which both the diffusion mobility of carbon atoms and the tubular diffusion of vacancies along the cores of dislocations are activated.

Studies of the surface layers carried out by fine analysis methods revealed microcrack foci occurring under friction loading and found that their average sizes, which were identified, are from 0.8 to $2.0 \mu \mathrm{m}$ at a concentration of about $10^{16}-10^{18} \mathrm{~m}^{-3}$ (in volume by two or three orders less). The thickness of the surface layer with a high concentration of microcracks correlates with the porosity of the coating material.

Thus, the use of carbon frame structures in the composition of nanoscale coatings is a promising direction of surface engineering, providing a significant increase in wear resistance and durability of products.

This publication continues the cycle of systematic research on the creation of promising nanomaterial's to reduce friction coefficients and increase the wear resistance of tribocontacts.

\section{Conclusions}

The validity of the used methodologies and algorithms for conducting experimental studies was defined to improve the wear resistance of detonation nanoscale composite coatings due to intrastructural self-correction of endogenous microcracks by carbon frame structures in the form of nanotubes.

It is noted that activated carbon atoms not only form surface carbides, but due to their size they easily diffuse and are able to migrate to the places of formation of microcracks, which have excess surface energy. Due to chemical and van der Waals attraction, these carbon atoms block the development of microcracks and their subsequent annihilation.

It has been established that a high density of energy stored in the surface layer under conditions of tribomechanical interaction, with the additive influence of thermodynamic factors and specific pressures, causes the appearance of almost all possible physicochemical anomalous transformations in the solid phase in the frictional contact zone. In this case, as a result of the thermal destruction of carbides, structurally free $\alpha$-graphite is formed.

The obtained results illustrated that the antifriction surface thin-film layer containing graphite is formed during the running-in process, and its composition and equilibrium roughness is reproduced and maintained, forming an integral system of dynamically stable secondary structures. In the entire range of normal wear and tear, a distinctive feature of these secondary structures is that they represent an active environmental, in each microvolume of which energy is accumulated and released. 
It has been established that for the formation of processes of intrastructural self-correction of endogenous microcracks in the near-surface layers, not only activated carbon atoms are needed, but also the influence of the operating temperature and the effect of compressive stress fields that cover the volume of microcracks.

The test results prove that partial healing of endogenous microcracks accumulating in the surface layers during friction due to their intrastructural self-correction using carbon frame structures in the form of nanotubes more than doubles the durability of coatings.

\section{Acknowledgements}

The authors thank the academician of NAS of Ukraine Yury F. Snezhkin and corresponding member of NAS of Ukraine Natalia M. Fialko for their support and participation in the discussion of this article.

\title{
References
}

1. Petrov, A. I., \& Razuvaeva, M. V. (2005). Initial Stage of Void and Crack Healing in Polycrystalline Metals under Uniform Compression. Physics of The Solid State, Vol. 47(5), pp. 907-912, doi: 10.1134/1.1924854.

2. Dienwiebel, M., Verhoeven, G. S., Pradeep, N., Frenken, J. W. M., Heimberg, J. A., \& Zandbergen, H. W. (2004). Superlubricity of graphite. Physical Review Letters, Vol. 92, pp. 448-451, doi: 10.1103/PhysRevLett.92.126101.

3. Kukudzhanov, K. V., \& Levitin, A. L. (2015). About the treatment of high energy pulsed electromagnetic field on the microcracks in elastoplastic conductive material. Problems of Strength and Plasticity, No. 77, pp. 217-226.

4. Song, H., Wang, Z.-J., \& Gao, T.-J. (2007). Effect of high density electropulsing treatment on formability of TC4 titanium alloy sheet. Transactions of Nonferrous Metals Society of China, No. 17, pp. 87-92, doi: 10.1016/S1003-6326(07)60053-3.

5. Stepanov, G. V., Kharchenko, V. V., Kotlyarenko, A. A., \& Babutskii, A. I. (2013). Effect of Pulsed Magnetic Field Treatment on the Fracture Resistance of a Cracked Specimen. Strength of Materials, Vol. 45(2), pp. 154-162.

6. Gallo, F., Satapathy, S., \& Ravi-Chandar, K. (2011). Melting and crack growth in electrical conductors subjected to shortduration current pulses. International Journal of Fracture, Vol. 167(2), pp. 183-193, doi: 10.1007/s10704-010-9543-0.

7. Kotrechko, S. A., \& Meshkov, Yu. A. (2008). Ultimate Strength. Crystals, Metals, Constructions: Monograph. Naukova Dumka, Kyiv, Ukraine.

8. Shapoval, A. A., Mos'pan, D. V., \& Dragbetskii, V. V. (2016). Production of periodic bars by vibrational drawing. Steel in Translation, Vol. 46(7), pp. 474-478, doi: 10.3103/S096709121607007X.

9. Babak, V. P., Shchepetov, V. V., Mirnenko, V. I., \& Yakovleva, M. S. (2016). High-temperature wear-resistant nanomaterial. Patent, No. 11394, Ukraine, IPC (2006): B22F 7/00, C22C 27/02 (2006.01), C23C 4/126 (2016.01), C23C 4/067 (2016.01), Institute of Technical Thermophysics of the National Academy of Sciences of Ukraine, No. a201601802, stated in 25.02.2016, published in 27.03.2017, bulletin No. 6/2017.

10. Veprek, S., Veprek-Heijman, M. G. J., Karvankova, P., \& Prochazka, J. (2005). Different approaches to super hard coatings and nanocomposites. Thin Solid Films, Vol. 476, pp. 1-29, doi: 10.1016/j.tsf.2004.10.053.

\section{Підвищення зносостійкості покриттів за рахунок внутрішньоструктурного самокорегування}

\author{
Бабак В. П., Більчук Є. Ю., Щепетов В. В.
}

Інститут технічної теплофізики НАН України, вул. Желябова, 2а, 03057, м. Київ, Україна

\begin{abstract}
Анотація. Запропоновано механізм блокування та подальшої анігіляції ендогенних мікротріщин за рахунок їх внутрішньоструктурної самокорекції. Встановлено, що під час трибомеханічних процесів фрикційної взаємодії в умовах адитивного впливу температурних флуктуацій і питомих навантажень у контактній зоні відбувається одночасна дія всіх можливих впливів з точки зору фізико-хімічних аномальних перетворень у твердій фазі, результатом яких $є$ термічний розклад карбідів і утворення структурно вільного $\alpha$ - графіту. Результати, отримані під час випробувань, дозволяють припустити, що антифрикційний поверхневий шар, що містить графіт, утворюється у режимі прироблення, а його склад, як і рівноважна шорсткість, відтворюються і підтримуються, утворюючи цілісну систему динамічно стійких зносостійких структур у всьому діапазоні нормального зношення.
\end{abstract}

Ключові слова: детонаційне напилення, зносостійкість, поверхневий шар, структурна пристосованість, легування. 